\title{
Monitoring Penyimpanan Kebutuhan Pokok Menggunakan Thinkspeak Berbasis IoT
}

\author{
Andi Abdullah \\ Jurusan Teknik Informatika \\ STMIK Tunas Bangsa Lampung
}

\begin{abstract}
Abstrak- Sistem monitoring kebutuhan pokok merupakan sebuah sistem yang digunakan untuk melihat ketersediaan kebutuhan bahan pokok. Pentingnya sistem monitoring kebutuhan pokok adalah untuk mengetahui jumlah ketersediaan bahan pokok setiap saat, sehingga apabila ketersediaan kebutuhan pokok berkurang atau habis pengguna dapat memenuhi kebutuhan pokok tersebut. Penelitian ini akan merancang sistem monitoring kebutuhan pokok menggunakan Internet of Things (IoT). IoT adalah sebuah konsep/skenario dimana suatu objek yang memiliki kemampuan untuk mentransfer data melalui jaringan tanpa memerlukan interaksi manusia ke manusia atau manusia ke komputer. Sistem ini menggunakan sensor load cell untuk mengukur berat beras dan sensor limit switch untuk menghitung jumlah telur. Data yang dihasilkan sensor akan diproses oleh arduino dan dikirimkan ke website thingspeak. Proses pengiriman data dari arduino ke thingspeak melalui ethernet shield dan router yang terhubung ke internet menggunakan modem, kemudian dimonitoring menggunakan smartphone android. Hasil uji coba membuktikan bahwa sistem ini dapat mengirimkan informasi yang akurat dari manapun tanpa terhalang jarak, selama sistem terhubung dengan internet.
\end{abstract}

Kata Kunci : IoT, monitoring, android, arduino, limit switch, load cell

\section{PENDAHULUAN}

Penyimpanan adalah suatu kegiatan untuk mengamankan barang atau benda milik pribadi yang dianggap berharga (KBBI, 2012). Sedangkan alat penyimpanan yaitu suatu media untuk meletakan barang atau benda. Tempat penyimpanan yang ada yaitu setiap benda memiliki tempat penyimpanan masing-masing sesuai dengan jenis, ukuran dan jumlahnya, hal ini dilakukan guna mempermudah dalam mencari dan mengumpulkan benda sesuai jenisnya. Keunggulan dari tempat penyimpanan yang ada yaitu setiap tempat penyimpanan didesain sedemikian rupa sehingga barang yang disimpan akan terlindungi.

Tempat penyimpanan yang ada memiliki kekurangan, salah satu contohnya ketika pengguna ingin mengetahui persediaan yang disimpan, maka pengguna harus melihat secara langsung ke tempat penyimpanan. Hal ini kurang efektif karena membutuhkan 
waktu yang cukup lama, ditambah dengan terbatasnya ingatan manusia yang sering lupa. Terkait dengan monitoring penyimpanan kebutuhan pokok, telah ada penelitian yang dilakukan oleh (Muktiawan \& Nurfiana, 2016) tentang monitoring kebutuhan pokok menggunkan android berbasis mikrokontroler. Peneliti menggunakan sensor limit switch untuk menghitung jumlah telur, sensor load cell untuk menghitung berat beras, mikrokontroler arduino sebagai kontrol, android sebagai tampilan untuk mengetahui jumlah persediaan bahan pokok yang dapat diakses melalui wifi. Penelitian sebelumnya memiliki kekurangan yaitu dapat mengakses informasi kebutuhan pokok dari perangkat smartphone ke perangkat keras dengan jarak maksimal 25 meter. Perlu adanya penambahan fungsi sistem pada jarak aksesnya supaya pengguna dapat memonitoring persediaan pokok dari manapun. Perbaikan sistem dapat dilakukan dengan menggunakan IoT(Internet of Things). IoT adalah sebuah konsep/skenario dimana suatu objek yang memiliki kemampuan untuk mentransfer data melalui jaringan tanpa memerlukan interaksi manusia ke manusia atau manusia ke komputer. Seperti penelitian yang dilaku kan oleh (Yuliant, Salahudin, \& Kowanda, 2015), peneliti menggunakan sistem IoT untuk memonitoring inkubator bayi. Dengan menggunakan internet sistem dapat diakses dari mana saja, sehingga pengguna dapat mengetahui persediaan kebutuhan pokok berupa beras dan telur dari manapun.

Tujuan dari penelitian ini yaitu menghasilkan sistem yang mampu memonitoring kebutuhan pokok dari manapun dan kapanpun secara real time, reliable dan otomatis.

\section{LANDASAN TEORI}

Penelitian dimulai dengan penelusuran penelitian-penelitian terdahulu serta berhubungan, diantaranya sebagai berikut :

1. Sistem Keamanan Dan Monitoring Rumah Pintar Secara Online Menggunakan Perangkat Mobile. (Abidin \& Lestariningati, 2014).

2. Rancang Aplikasi Pemantau Suhu dan Kelembapan Pada Inkubator Bayi Berbasis Internet (Yuliant, Salahudin, \& Kowanda, 2015).

3. Perancangan Sistem Monitoring PH Air Berbasis Internet di PDAM Tirta Kepri (Nuriman, Pramana, \& Nusyirwan, 2016).

4. Sistem Monitoring Cuaca Menggunakan ESP8266 Berbasis Web Internet of Things (IoT) (Rakhman, 2016).

5. Sistem Monitoring Suhu Jarak Jauh Berbasis Internet of Things Menggunakan Protokol MQTT (Budioko, 2016).

6. Rancang Bangun Monitoring Alat Penyimpanan Kebutuhan Pokok Melalui Android Berbasis Mikriokontroler (Muktiawan \& Nurfiana, 2016)

\section{A. Internet of Things (IoT)}

Internet of Things(IoT) adalah sebuah konsep/skenario dimana suatu objek yang memiliki kemampuan untuk mentransfer data melalui jaringan tanpa memerlukan interaksi manusia ke manusia atau manusia ke komputer." A Things" pada Internet of Things dapat didefinisikan sebagai subjek misalkan orang dengan monitor implant jantung, hewan peternakan dengan transponder biochip, sebuah mobil yang telah dilengkapi built-in sensor untuk memperingatkan pengemudi ketika tekanan ban rendah. Sejauh ini, IoT paling erat hubungannya dengan komunikasi machine-to-machine(M2M) di bidang manufaktur dan listrik, perminyakan dan gas. Produk dibangun dengan kemampuan komunikasi $M 2 M$ yang sering disebut dengan sistem cerdas atau "smart". 


\section{B. ThingSpeak}

ThingSpeak adalah platformopen source Internet of Things (IOT) aplikasi dan API(Application Programming Interface )untuk menyimpan dan mengambil data dari hal menggunakan protokol HTTP melalui Internet atau melalui Local Area Network. ThingSpeak memungkinkan pembuatan aplikasi sensor logging, aplikasi lokasi pelacakan, dan jaringan sosial hal dengan update status. ThingSpeak awalnya diluncurkan oleh ioBridge pada tahun 2010 sebagai layanan untuk mendukung aplikasi IOT. ThingSpeak telah terintegrasi dukungan dari numerik komputasi perangkat lunak MATLAB dari MathWorks. Memungkinkan ThingSpeak pengguna untuk menganalisis dan memvisualisasikan data yang diunggah menggunakan Matlab tanpa memerlukan pembelian lisensi Matlab dari MathWorks.

\section{Smartphone}

Smartphone (telephon pintar) adalah telepon yang menyediakan fitur yang berada diatas dan di luar kemampuan sederhana (Safaat, 2011). Smartphone pertama diberi nama Simon yang dikembangkan oleh IBM (International Business Machines Corporation) pada tahun 1992 dan terpilih sebagai product of the year oleh COMDEX (Computer Dealers Exposition). Simon direlease pada tahun 1993 oleh BellSouth, selain fitur telephone dan SMSSimon dilengkapi dengan calendar, address book, world clock, notepad, email, fax, dan games. Setelah itu banyak prodak sejenis yang dikeluarkan oleh berbagai vendor berbeda seperti Nokia. Sistem operasi yang digunakan pada smartphone berbeda-beda tetapi yang paling banyak digunakan saat ini adalah sistem operasi yang berbasis Android dari google. Berikut adalah salah satu sistem operasi pada smartphone dan salah satu versi sistem operasi.

\section{Android}

Android adalah sistem operasi untuk telepon seluler yang berbasis Linux. Android menyediakan platform yang bersifat open source bagi para pengembang untuk menciptakan sebuah aplikasi. Awalnya, Google Inc. Mengakuisi Android Inc. Yang mengembangkan software untuk ponsel yang berada di Palo Alto, California Amerika Serikat. Kemudian untuk mengembangkan Android, dibentuklah Open Handset Alliance, yaitu konsorsium dari 34 perusahaan hardware, software dan telekomunikasi, termasuk Google, HTC, Intel, Motorola, Qualcomm, T-Mobile, 20 dan Nvidia. Telepon pertama yang memakai sistem operasi Android adalah HTC Dream, yang dirilis pada 22 Oktober 2008. Pada penghujung tahun 2009 diperkirakan di dunia ini paling sedikit terdapat 18 jenis (Safaat H, 2011).

\section{E. Modul Arduino Mega 2560}

Arduino mega 2560 merupakan sebuah board mikrokontroler berbasis ATMega2560 (W, 2015). Modul ini memiliki 54 digital input/output dmana 14 digunakan untuk PWM output dan 16 digunakan sebagai analog input, 4 port serial, $16 \mathrm{MHz}$ osilator Kristal, koneksi USB, power jack, ICISP Header, dan tombol reset. Memiliki flash memory sebesar 256KB sangat cukup untuk menampung program yang banyak. Arduino mega 2560 tidak memerlukan flash program external karena di dalam chip mikrokontroler Arduino telah diisi dengan bootloader yang membuat proses upload program yang kita buat menjadi lebih sederhana dan cepat. Untuk koneksi dengan komputer sudah tersedia RS232 to TTL converter atau menggunakan chip USB ke serial converter seperti FTDI FT232.

\section{F. Arduino Ethernet Shield}

Ethernet Shield menambah kemampuan arduino board agar terhubung ke jaringan komputer. Ethernet shield berbasiskan cip ethernet Wiznet W5100. Ethernet library digunakan dalam menulis program agar arduino board dapat terhubung ke jaringan dengan menggunakan arduino ethernet shield. Pada ethernet shield terdapat sebuah slot micro-SD, yang dapat digunakan untuk menyimpan file yang dapat diakses melalui jaringan (Syahwi, 2017).

\section{G. Load Cell}

Load cell atau biasa disebut dengan deformasi strain gauge adalah sensor yang digunakan untuk mengukur berat atau beban dari suatu benda dalam ukuran besar. Sensor load cell ini sering diaplikasikan pada jembatan timbang mobil atau alat ukur berat dalam skala besar. (C) 2018 PTIPD SNJ All rights reserved 
Sensor load cell adalah grid metal-foil yang tipis yang dilekatkan pada permukaan dari struktur. Apabila komponen atau struktur dibebani, terjadi strain dan ditransmisikan ke foil grid. Tahanan foil grid berubah sebanding dengan strain induksi beban (Sugirawan, Muntini, \& Pramono, 2009). Transduksi massa dapat bervariasi bergantung pada perubahan parameter fisis yang digunakan. Sensor massa juga dapat menggunakan divais berbasis piezoresistif, kapasitif, mekanis dan lain-lain. Piezoresistif yang popular adalah load cell yang memanfaatkan perubahan resistansi strain gauge setiap mendapat deformasi dari posisi setimbang sebagai akibat pembebanan massa tertentu. Strain adalah sejumlah deformasi pada material sebagai pengaruh dari aplikasi gaya.

\section{H. Limit Switch}

Limit switch merupakan jenis saklar yang dilengkapi dengan katup yang berfungsi menggantikan tombol. Prinsip kerja limit switch sama seperti saklar push on yaitu hanya akan menghubung pada saat katubnya ditekan pada batas penekanan tertentu yang telah ditentukan dan akan memutus saat saat katub tidak ditekan. Limit switch termasuk dalam kata gori sensor mekanis yaitu sensor yang akan memberikan perubahan elektrik saat terjadi perubahan mekanik pada sensor tersebut. Penerapan dari limit switch adalah sebagai sensor posisi suatu benda (objek) yang bergerak. Prinsip kerja limit switch

diaktifkan dengan penekanan pada tombolnya pada batas/ daerah yang telah ditentukan sebelumnya sehingga terjadi pemutusan atau penghubungan rangkaian dari rangkaian tersebut. Limit switch memiliki dua kontak yaitu NO (Normally Open) dan kontak NC (Normally Close) dimana salah satu kontak akan aktif jika tombolnya tertekan.

\section{Modul Weighing Sensor HX711}

HX711 adalah modul timbangan, yang memiliki prinsip kerja mengkonversi perubahan yang terukur dalam perubahan resistansi dan mengkonversinya ke dalam besaran tegangan melalui rangkaian yang ada. Modul melakukan komunikasi dengan computer/mikrokontroler melalui TTL232. Modul HX711 merupakan sebuah $O p$-amp namun kelebihan dari modul ini adalah struktur yang sederhana, mudah dalam penggunaan, hasil yang stabil dan reliable, memiliki sensitivitas tinggi, dan mampu mengukur perubahan dengan cepat. Jadi sangat cocok untuk dijadikan penguat sensor load cell. Prinsip kerja dari modul ini yaitu ketika bagian lain yang lebih elastic mendapat tekanan, maka pada sisi lain akan mengalami perubahan regangan yang sesuai dengan yang dihasilkan oleh straingauge, hal ini terjadi karena ada gaya yang seakan melaw an pada sisi lainnya. Perubahan nilai resistansi yang diakibatkan oleh perubahan gaya diubah menjadi nilai tegangan oleh rangkaian pengukuran yang ada. Dan berat dari objek yang diukur dapat diketahui dengan mengukur besarnya nilai tegangan yang timbul.

\section{J. TP-Link TL-MR3420}

TP-Link TL-MR3420 ini merupakan sebuah wirelesrouter yang sangat lengkap. Selain dapat membagi koneksi kabel/ADSL internet, router ini juga dapat digunakan untuk berbagi koneksi 3G. Setiap router access point memilik alamat IP bawaan yaitu 192.168.1.1. Alamat IP ini digunakan untuk melakukan konfigurasi sistem. Pada perangkat ini tersedia sebuah port USB untuk mencolokan modem.

\section{K. Modem}

Modem berasal dari singkatan ModulatorDemodulator. Modulator merupakan bagian yang mengubah sinyal informasi ke dalam sinyal pembawa (carrier) dan siap untuk dikirimkan, sedangkan Demodulator adalah bagian yang memisahkan sinyal informasi (yang berisi data atau pesan) dari sinyal pembawa yang diterima sehingga informasi tersebut dapat diterima dengan baik (Situmorang, 2012). 


\section{METODOLOGI PENELITIAN}

Metode penelitian yang dilakuakn pada penelitian ini yaitu studi literatur, perancangan sistem, analisa kebutuhan, implementasi dan pengujian. Berikut adalah gambar blok diagram sistem seperti pada gambar 1 .

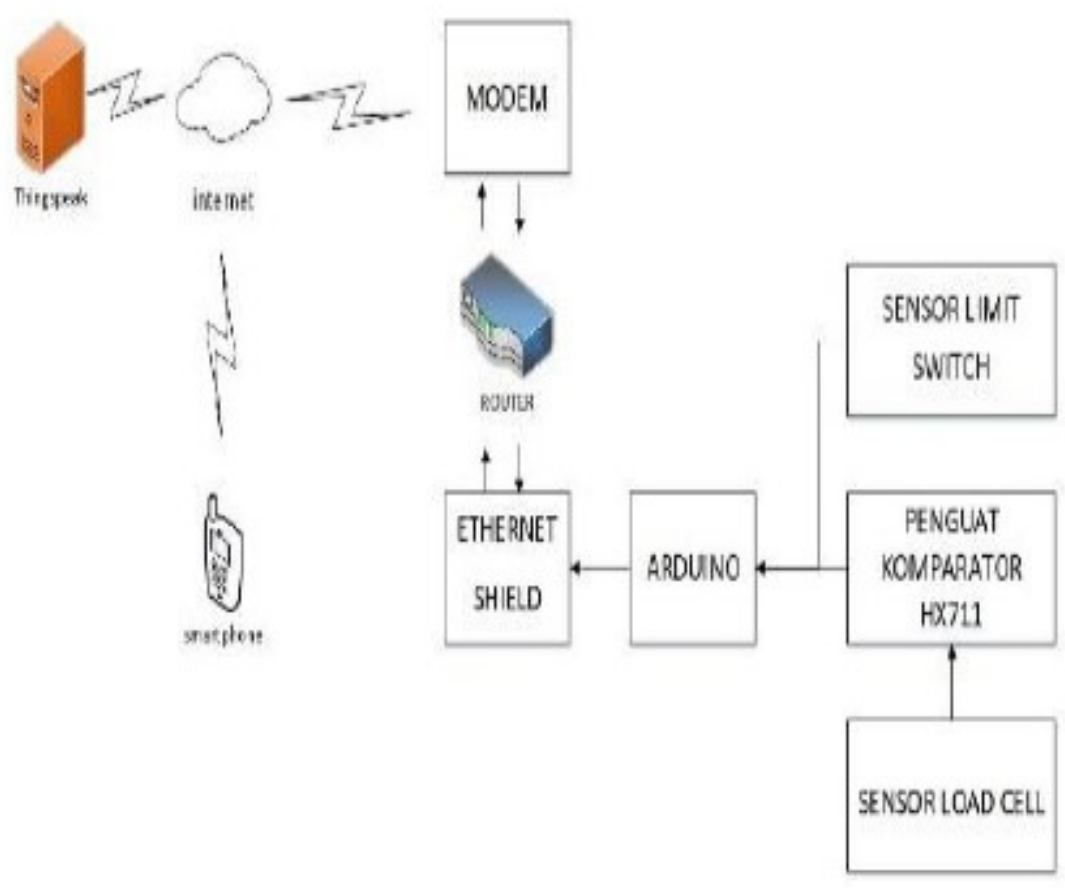

Gambar 1 : Blok Diagram Sistem

Sistem ini bekerja menggunakan 2 buah sensor, sensor load cell dan sensor limit switch. Sensor load cell digunakan untuk mengukur berat beras. Apabila sensor load cell mendapatkan beban maka akan terjadi perubahan resistansi yang berpengaruh terhadap output tegangan yang dikeluarkan. Tegangan yang dihasilkan akan di kuatkan oleh penguat komparator HX711 dan dikirimkan ke arduino. Sensor limit switch digunakan untuk menghitung jumlah telur. Sensor akan bekerja apabila switch dalam keadaan terhubung $(O N)$. Saat sensor limit switch dalam kondisi terhubung maka akan menghasilkan tegangan, tegangan tersebut akan dikirimkan ke arduino untuk diolah sehingga menghasilkan jumlah telur. Data yang dikirimkan oleh sensor load cell dan limit switch akan diproses oleh arduino untuk menentukan berat beras dan jumlah telur dan akan disimpan sementara di dalam ROMethernet shield. Data yang tersimpan pada ROM ethernet shield akan dikirim ke website thingspeak menggunakan router yang telah terhubung ke internet menggunakan modem. Pada website thingspeak akan ditampilkan data sesuai dengan yang dikirimkan oleh ethernet shield dan akan selalu berubah selama 30 detik secara real time. Dan data akan diambil dan ditampilkan oleh aplikasi yang ada di smartphone. Untuk rangkaian keseluruhan dapat dilihat pada gambar 2 . 


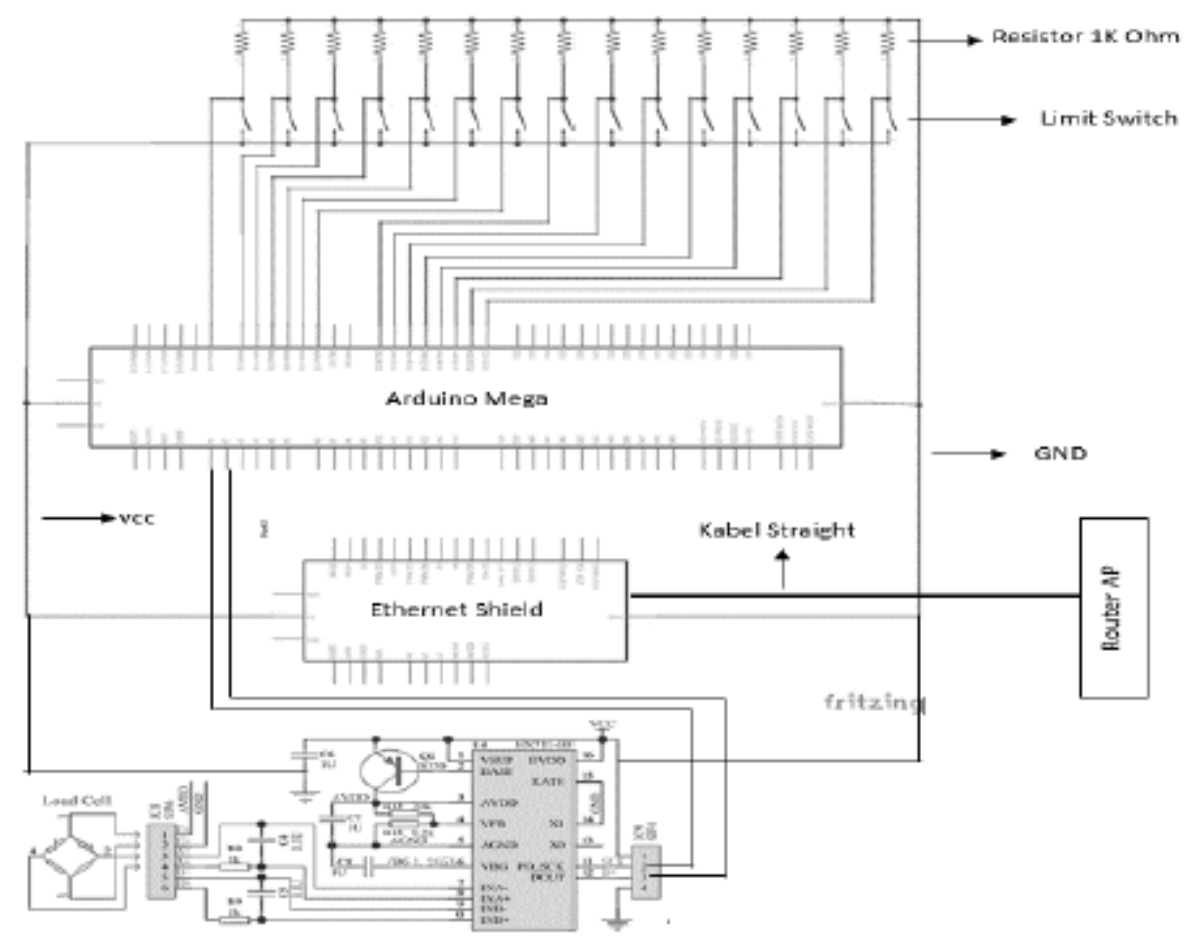

Gambar 2 : Rangkaian Keseluruhan

Tabel 1 : Penggunaan PIN

\begin{tabular}{|c|c|c|c|c|}
\hline No & $\begin{array}{c}\text { Pin } \\
\text { Input } \\
\text { Arduino }\end{array}$ & Keterangan & $\begin{array}{c}\text { Pin } \\
\text { Output } \\
\text { Sensor }\end{array}$ & Keterangan \\
\hline 1 & A0 & Pin Input Analog 0 & SCK & Pin Output SCK load cell \\
\hline 2 & A1 & Pin Input Analog 1 & B+ & Pin Output B+ load cell \\
\hline 3 & D2 & Pin Input Digital 2 & LS 1 & Kaki Output Limit Switch 1 \\
\hline 4 & D3 & Pin Input Digital 3 & LS 2 & Kaki Output Limit Switch 2 \\
\hline 5 & D4 & Pin Input Digital 4 & LS 3 & Kaki Output Limit Switch 3 \\
\hline 6 & D5 & Pin Input Digital 5 & LS 4 & Kaki Output Limit Switch 4 \\
\hline 8 & D6 & Pin Input Digital 6 & LS 5 & Kaki Output Limit Switch 5 \\
\hline 9 & D7 & Pin Input Digital 7 & LS 6 & Kaki Output Limit Switch 6 \\
\hline 10 & D8 & Pin Input Digital 8 & LS 7 & Kaki Output Limit Switch 7 \\
\hline 11 & D14 & Pin Input Digital 14 & LS 8 & Kaki Output Limit Switch 8 \\
\hline 12 & D15 & Pin Input Digital 15 & LS 4 & Kaki Output Limit Switch 9 \\
\hline 13 & D16 & Pin Input Digital 16 & LS 10 & Kaki Output Limit Switch 10 \\
\hline 14 & D17 & Pin Input Digital 17 & LS 11 & Kaki Output Limit Switch 11 \\
\hline 15 & D18 & Pin Input Digital 18 & LS 12 & Kaki Output Limit Switch 12 \\
\hline 16 & D19 & Pin Input Digital 19 & LS 13 & Kaki Output Limit Switch 13 \\
\hline 17 & D20 & Pin Input Digital 20 & LS 14 & Kaki Output Limit Switch 14 \\
\hline 18 & D21 & Pin Input Digital 21 & LS 15 & Kaki Output Limit Switch 15 \\
\hline & & & &
\end{tabular}




\section{HASIL DAN PEMBAHASAN}

Hasil dari pengujian sensor limit switch pada tiap-tiap tempat penyimpanan telur. Output tegangan yang dihasilkan akan dilogikakan untuk menghitung jumlah telur. Ditambilkan pada tabel 2 berikut :

Tabel 2 : Hasil Pengujian Sensor Limit Switch

\begin{tabular}{|c|c|c|c|}
\hline $\begin{array}{c}\text { Uji } \\
\text { coba } \\
\text { ke }\end{array}$ & Sensor & Kondisi & $\begin{array}{l}\text { Output } \\
\text { tegangan } \\
\text { (V) }\end{array}$ \\
\hline 1 & Limit switch 1 & ON & 4.63 \\
\hline 2 & Limit switch 1 & OFF & 0 \\
\hline 3 & Limit switch 2 & ON & 4.63 \\
\hline 4 & Limit switch 2 & OFF & 0 \\
\hline 5 & Limit switch 3 & ON & 4.63 \\
\hline 6 & Limit switch 3 & OFF & 0 \\
\hline 7 & Limit switch 4 & ON & 4.63 \\
\hline 8 & Limit switch 4 & OFF & 0 \\
\hline 9 & Limit switch 5 & $\mathrm{ON}$ & 4.63 \\
\hline 10 & Limit switch 5 & OFF & 0 \\
\hline 11 & Limit switch 6 & ON & 4.63 \\
\hline 12 & Limit switch 6 & OFF & 0 \\
\hline 13 & Limit switch 7 & $\mathrm{ON}$ & 4.63 \\
\hline 14 & Limit switch 7 & OFF & 0 \\
\hline 15 & Limit switch 8 & $\mathrm{ON}$ & 4.63 \\
\hline 16 & Limit switch 8 & OFF & 0 \\
\hline 17 & Limit switch 9 & ON & 4.63 \\
\hline 18 & Limit switch 9 & OFF & 0 \\
\hline 19 & Limit switch 10 & ON & 4.63 \\
\hline 20 & Limit switch 10 & OFF & 0 \\
\hline 21 & Limit switch 11 & $\mathrm{ON}$ & 4.63 \\
\hline 22 & Limit switch 11 & OFF & 0 \\
\hline 23 & Limit switch 12 & $\mathrm{ON}$ & 4.63 \\
\hline 24 & Limit switch 12 & OFF & 0 \\
\hline 25 & Limit switch 13 & $\mathrm{ON}$ & 4.63 \\
\hline 26 & Limit switch 13 & OFF & 0 \\
\hline 27 & Limit switch 14 & ON & 4.63 \\
\hline 28 & Limit switch 14 & OFF & 0 \\
\hline 29 & Limit switch 15 & ON & 4.63 \\
\hline 30 & Limit switch 15 & OFF & 0 \\
\hline
\end{tabular}

Berdasarkan uji coba seperti pada tabel 3, berat awal beras $2 \mathrm{~kg}$ dilakukan pengambil an beras sebanyak satu genggam sebanyak 5 kali. Dimana pada tiap pengambilan beras mengalami penurunan berat hingga 1201 gram. Dapat disimpulkan bahwa sensor strain gauge sangat sensitif terhadap perubahan berat suatu benda. 
Tabel 3 : Hasil Pengujian Sensor Load Cell

\begin{tabular}{|c|c|c|}
\hline \multirow{2}{*}{ No } & $\begin{array}{c}\text { Berat } \\
\text { beras } \\
\end{array}$ & $\begin{array}{c}\text { Berat beras Terukur } \\
\text { pada tampilan } \\
\text { aplikasi (gram) }\end{array}$ \\
\hline 1 & \multirow{4}{*}{$2 \mathrm{~kg}$} & 1708 \\
& & 1662 \\
& & 1499 \\
3 & & 1375 \\
\hline 4 & & 1201 \\
\hline 5 & &
\end{tabular}

Tabel 4 : Hasil Pegujian Waktu Respon dari Arduino ke Thingspeak

\begin{tabular}{|c|c|c|c|c|c|c|}
\hline \multirow{2}{*}{$\begin{array}{c}\text { Uji } \\
\text { coba } \\
\text { ke }\end{array}$} & \multicolumn{2}{|c|}{ Aksi yang dilakukan } & \multirow{2}{*}{ Waktu respon } & \multicolumn{2}{|c|}{ Hasil } & \multirow{2}{*}{$\begin{array}{c}\text { Keterang } \\
\text { an }\end{array}$} \\
\hline & Telur & Beras & & Telur & Beras & \\
\hline 1 & Meletakan 1 telur & - & 22 detik & 1 butir & 0 gram & Sesuai \\
\hline 2 & $\begin{array}{c}\text { Menambahkan } 3 \\
\text { telur }\end{array}$ & - & 10 detik & 4 butir & 0 gram & Sesuai \\
\hline 3 & $\begin{array}{c}\text { Menambahkan } 5 \\
\text { telur }\end{array}$ & - & 14 detik & 9 butir & 0 gram & Sesuai \\
\hline 4 & - & Meletakan beras & 14 detik & 9 butir & 1708 gram & Sesuai \\
\hline 5 & - & Mengambil beras 1 genggam & 14 detik & 9 butir & 911 gram & Sesuai \\
\hline 6 & - & Mengambil beras 1 genggam & 13 detik & 9 butir & 826 gram & Sesuai \\
\hline 7 & - & Mengambil beras 1 genggam & 30 detik & 9 butir & 739 gram & Sesuai \\
\hline 8 & Mengurangi 2 telur & Mengambil beras 1 genggam & 14 detik & 7 butir & 621 gram & Sesuai \\
\hline 9 & Mengurangi 1 telur & Mengambil beras 1 genggam & 15 detik & 6 butir & 513 gram & Sesuai \\
\hline 10 & Mengurangi 1 telur & Mengambil beras 1 genggam & 30 detik & 5 butir & 420 gram & Sesuai \\
\hline
\end{tabular}

Berdasarkan uji coba pada tabel 4, dengan melakukan sebanyak 10 kali percobaan didapat jumlah rata-rata yaitu 17,6 detik. Jumlah telur dan berat beras yang ditampilkan sesuai dengan yang dikirimkan oleh arduino dan data yang dihasilkan sangat akurat. Yang berbeda adalah waktu respon saat update data pada tampilan website thingspeak hal ini dipengaruhi oleh bandwith. Semakin cepat bandwith, semakin cepat dalam menerima dan mengirim data.

\section{KESIMPULAN}

Berdasarkan perancangan, pengujian dan analisa sistem yang telah dilakukan, dapat disimpulkan bahwa sistem ini memanfaatkan jaringan internet dan memanfaatkan thingspeak sebagai media kendali, mikrokontroler arduino mega 2560 sebagai kendali yang terintegrasi terhadap aplikasi berbasis android. Maka dapat dimonitoring persediaan kebutuhan bahan pokok dengan kinerja jarak jangkauan lebih dari 25 meter dengan kecepatan rata-rata 35,42 detik.

\section{REFERENSI}

[1] Abidin, Z., \& Lestariningati, S. I. (2014). SISTEM KEAMANAN DAN MONITORING RUMAH PINTAR SECARA ONLINE MENGGUNAKAN PERANGKAT MOBILE. Jurnal Teknik Komputer Unikom, 13-17.Vol.3.

[2] Budioko, T. (2016). SISTEM MONITORING SUHU JARAK JAUH BERBASIS INTERNET OF THINGS MENGGUNAKAN PROTOKOL MQTT. Seminar Riset Teknologi Informasi (hal. 353-358). Yogyakaeta: STMIK AKAKOM.

[3] KBBI. (2012, Maret 5). Kamus Besar Bahasa Indonesia (KBBI). Diambil kembali dari Web Site Kamus Besar Bahasa Indonesia: https://kbbi.web.id/simpan

[4] Muktiawan, D. A., \& Nurfiana. (2016). RANCANG BANGUN MONITORING ALAT PENYIMPANAN KEBUTUHAN POKOK MELALUI ANDROID BERBASIS MIKROKONTROLER. Seminar Nasional Riset Terapan (hal. A28-A35). Banjarmasin : Politeknik Negeri Banjarmasin.

[5] Nuriman, R. F., Pramana, R., \& Nusyirwan, D. (2016). PERANCANGAN SISTEM MONITORING pH AIR BERBASIS INTERNET DI PDAM TIRTA KEPRI .Tanjung Pinang: Universitas Maritim Raja Ali Haji. 
[6] Rakhman, E. A. (2016). SISTEM MONITORING CUACA MENGGUNAKAN ESP8266 BERBASIS WEB INTERNET OF THINGS. Yogyakarta: Universitas Teknologi Yogyakarta.

[7] Safaat H, N. (2011). Pemograman Aplikasi Mobile Smartphone dan Tablet PC Berbasis Android. Bandung: Informatika Bandung.

[8] Situmorang, E. (2012). Rancang Bangun Alat Buka Tutup Pintu Pagar Dengan Menggunakan Handphone Dan Keypad. Manado: UNSRAT.

[9] Sugirawan, I., Muntini, M. S., \& Pramono, Y. H. (2009). DESAIN DAN KARAKTERISASI LOAD CELL TIPE CZL601 SEBAGAI SENSOR MASA UNTUK MENGUKUR DRAJAT LAYU PADA PENGOLAHAN TEH HITAM. SURABAYA: ITS SURABAYA.

[10] Syahwi, M. (2017). Panduan Mudah Belajar Arduino Menggunakan Simulasi Proteus. Yogyakarta: ANDI.

[11] W, H. S. (2015). Mudah Belajar Mikrokontroller dengan Arduino. Bandung: Widya Media .

[12] Yuliant, A., Salahudin, N. S., \& Kowanda, A. (2015). Rancang Aplikasi Pemantau Suhu dan Kelembapan Pada Inkubator Bayi Berbasis Internet. Seminar Nasional Aplikasi Teknologi Informasi (hal. 7-10). Yogyakarta: Universitas Gunadarma.

[13] Y. Marine and S. Saluky, "Penerapan IoT untuk Kota Cerdas", itej, vol. 3, no. 1, pp. 36 - 47, Jul. 2018. 